\title{
Megosztásos gazdaság - a megosztás vagy a fogyasztás tere?
}

\section{Sharing economy - the space of sharing or consumption?}

\author{
LAZÁNYI ORSOLYA, VERESS TAMÁS, BÁRSONY FANNI
}

LAZÁNYI Orsolya: doktorjelölt, Budapesti Corvinus Egyetem, Vállalatgazdaságtan Intézet, Döntéselmélet Tanszék; 1093 Budapest, Fővám tér 8.; orsolya.lazanyi@uni-corvinus.hu; http://orcid.org/0000-0002-3232-091X

VERESS Tamás: PhD hallgató, Budapesti Corvinus Egyetem, Gazdaságetikai Központ; 1093 Budapest, Fővám tér 8.; tamas.veress@netorient.hu; https://orcid.org/0000-00019945-2901

BÁRSONY Fanni: doktorjelölt, Budapesti Corvinus Egyetem, Szociológia Doktori Iskola; 1093 Budapest, Közraktár u. 4-6.; fanni.barsony@uni-corvinus.hu; http://orcid.org/ 0000-0002-2447-1873

KULCSSZAVAK: megosztásos gazdaság; beágyazottság; szubsztantív gazdaság; intézményi logikák; közösségi javak

ABSZTRAKT: Cikkünkkel - Polányi Károly általános gazdaságelméletére és a közösségi javak szakirodalmára támaszkodva - a megosztásos gazdaságról folyó diskurzushoz kapcsolódunk. Kiindulópontunk a megosztásos gazdaság önellentmondása: míg a „megosztás" fogalma egy közösségre, egymást ismerő egyének közötti kölcsönösségen alapuló kapcsolataira, addig a „gazdaság” piaci műveletekre, idegen emberek közötti tranzakciók terére és gyakorlataira utal. Érvelésünk szerint az önellentmondást az adott megosztási térben működő eltérő intézményi logikák (felek közötti kapcsolódási módok, mint például a reciprocitás, a redisztribúció és az árucsere) idézik elő. Cikkünkben olyan elemzési keretet állítunk fel, mely érzékeny az adott megosztási térben működő intézményi logikákra, és ezáltal alkalmas lehet az egyes megosztási terek belső feltételeinek, sajátosságainak fel- és megismerésére. Vizsgálatunkhoz a közösségi javak szakirodalma szolgáltat további elemzési szempontokat. A közösségi javak olyan megosztási terekként értelmezhetőek, amelyek a piaci mechanizmusoktól eltérő (vagy a piacit más szempontnak alárendelő) és állami koordinációtól független intézményi logika mentén alakítják az erőforrások közös kezelését és fenntartását. Az eltérő intézményi logikák mellett a közösségi javak vizsgálata - a megosztásban résztvevők közötti kapcsolatok formájára, a döntéshozók körére, a tulajdonosi szerkezetre és annak közösséggel szembeni felelős formájára vonatkozóan - fontos szempontokkal gazdagíthatja a megosztásos gazdaság kutatását. A közösségi javak és megosztásos gazdaság szakirodalmának szintetizálásával felállított elméleti keretünket írásunkban a megosztási tér három illusztratív esetének elemzésére alkalmazzuk.

Orsolya LAZÁNYI: PhD candidate, Department of Decision Sciences, Institute of Business Economics, Corvinus University of Budapest; Fövám tér 8., H-1093 Budapest, Hungary; orsolya.lazanyi@uni-corvinus.hu; http://orcid.org/0000-0002-3232-091X

Tamás VERESS: PhD student, Business Ethics Center, Corvinus University of Budapest; Fővám tér 8., H-1093 Budapest, Hungary; https://orcid.org/0000-0001-9945-2901

Fanni BÁRSONY: PhD candidate, Doctoral School of Sociology, Corvinus University of Budapest; Közraktár u. 4-6., H-1093 Budapest, Hungary; fanni.barsony@uni-corvinus.hu; http://orcid.org/ 0000-0002-2447-1873

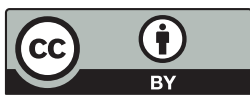


KEYWORDS: sharing economy; embeddedness; substantive economy; institutional logics; commons

ABSTRACT: The paper aims to contribute to the discussion of the sharing economy, relying on Karl Polanyi's substantive understanding of the economy and the commons literature. The spread of digital technology enabled the emergence of various sharing practices not only among neighbours but among geographically distant citizens across the globe. The ongoing debate has explored different types of sharing practices. However, the literature on sharing economy fails to differentiate the distinct meanings of sharing, namely sharing as a commercial activity and sharing as a social, solidarity practice. The confusion of the sharing economy derives from the paradoxical character of the sharing economy's two components; 'sharing' implies a community of close others and reciprocal relations, while the term 'economy' points to market mechanisms among distant others with a distinct set of ethics and social norms. The self-contradiction arises - we argue - from the different institutional logics (ways of interacting, such as reciprocity, redistribution and exchange) apparent in the given space of sharing. Therefore in our paper we aim to construct a framework, which is sensitive towards the different institutional logics and therefore capable of recognizing and analysing the various spaces of sharing on their own terms.

Beside institutional logics, the concept of the commons offers further analytical aspects to deepen understanding about sharing practices. The commons can be interpreted as spaces of sharing which operate based on institutional logics which are distinct from the market logic. The commons refer to social practices which aim to manage and maintain shared resources in a communal and democratic way, independently (or aiming to operate independently) from the market and state mechanisms. The literature of the commons concept explores analytical aspects that can enrich the analysis of spaces of sharing, such as the relationship among participants, participation in decision making, a form of ownership which is responsible toward the community or barriers to enter. Therefore, based on the substantive understanding of the economy complemented with the different aspects of the commons we create an analytical framework which can contribute to better explore sharing practices.

We apply the framework to three selected cases in order to demonstrate its applicability and to describe different sharing spaces; a communal sewing workshop, an online platform to share goods and services, and the example of co-housing. The three illustrative cases reveal that different institutional logics can be found parallel to each other which are based on but not limited to the ones identified by Polanyi. Thus our analytical framework and illustrative cases reveal that sharing economy should not be narrowed down and studied exclusively based on market exchange but as embedded in social interactions.

\section{Bevezetés}

A megosztásos gazdaság (sharing economy) olyan társadalmi és gazdasági rendszer, melyben a szolgáltatók és felhasználók (harmadik fél által tulajdonolt) digitális platformokon lépnek kapcsolatba egymással, és ott hozzáférést nyújtanak eszközeikhez, szolgáltatásaikhoz vagy ötleteikhez (Belk et al. 2019). A megosztás ugyanakkor nem új, a digitalizáció nyomán kialakult gyakorlat, hanem egyidős az emberiséggel, és ennek megfelelően kultúra- és kontextusfüggő. Nicholas A. John (2016) a megosztás társadalmi jelentéseit vizsgálva arra jut, hogy a megosztás gyűjtőfogalom. Különböző, pozitív értékjelentést hordozó társadalmi gyakorlatokra vonatkozik, melyek alternatívát képviselnek a kapitalizmussal társított, egymást eszközként kezelő személytelen kapcsolatokkal szemben (Bársony 2017). 
Innen a megosztásos gazdaság önellentmondása, belső feszültsége, melyet a megosztás és a gazdaság fogalmainak összekapcsolása idéz elő. Jelen cikkünkben a megosztásos gazdaság diskurzusához a fogalom önellentmondásának vizsgálatával csatlakozunk.

A hazai szakirodalomban feltáró-ismertető szerepet tölt be Dudás Gábor és Boros Lajos (2019) tanulmánya, melynek célja a megosztásos gazdaság fogalmi dilemmáinak, kihívásainak tárgyalása. Következtetésük alapján a megosztásos gazdaság csak részben értelmezhető a hagyományos gazdasági kategóriákon belül. Tanulmányunkban a megosztásos gazdaságot a hagyományos (formális) gazdasági szemlélettől, kategóriáktól eltérő elméleti keretek között vizsgáljuk, és új szempontokat kínálunk az elemzéshez.

A megosztás eltérő jelentéseit és a megosztásos gazdaság ellentmondását - Polányi Károly (1976) elméletére támaszkodva - a gazdaság szubsztantív értelmezésén keresztül kíséreljük meg feloldani. Tanulmányunk célja egy olyan vizsgálati keret felállítása, mely alkalmas az eltérő megosztási terek saját belső feltételeinek, racionalitásának fel- és megismerésére. A megosztásos gazdaság elemzését mélyítő szempontokat a megosztást szintén központi elemként taglaló közösségi javak (commons) szakirodalma nyújthat. A közösségi javak fenntartása köré szerveződő társadalmi gyakorlatok elmélete elsősorban a demokratikus müködés terén gazdagíthatja a megosztásos gazdaság vizsgálatát (Bradley, Pargman 2017). Az elmélet, mely a közösségi javakat önszerveződés útján létrejövő, és a piaci logikától, állami mechanizmusoktól egyaránt függetlenedni törekvő szerveződésekként írja le, lehetővé teszi a piaci cseréhez köthető más szempontok (úgymint: kik alakíthatják a szabályokat, kik rendelkezhetnek az interakciók révén létrejött értékekről) újraértékelését is.

A cikk első részében az elméleti keretet állítjuk fel, a második fejezetben különböző megosztási fogalmakra, a harmadikban eltérő gazdaság-megközelítésekre támaszkodunk, majd a közjavak elméletének a megosztásos gazdaság vizsgálata kapcsán releváns részeit mutatjuk be. A tanulmány második részében a kialakított elemzési keretet használjuk három, erre a célra kiválasztott megosztási tér vizsgálatára, végül megfogalmazzuk következtetéseinket.

\section{A megosztás eltérő társadalmi jelentései és ellentmondásai}

Andreas Wittel (2011) és Nicholas A. John $(2013,2016)$ szerint különböző társadalmi terekben eltérő tevékenységeket nevezhetünk megosztásnak. A megosztást társadalmi jelenségként vizsgáló szakirodalom egymás segítésére és társadalmi kapcsolatok ápolására irányuló tevékenységként azonosítja a fogalmat (Wittel 2011; John 2013; Price 1975). A megosztás társadalmi jelentésével foglalkozó szakirodalommal ellentétben ugyanakkor, a megosztásos gazdaságot érintő vizsgálatok (például Zilahy 2016; Szabó 2017) gyakran nem különböztetik meg a profit- 
maximalizálást célzó, kereskedelmi tevékenységként definiálható megosztást az olyan társadalmi gyakorlatoktól, melyek célja a szükségletek kielégítése társadalmi kapcsolatokon keresztül. Véleményünk szerint, a különbségtétel hiánya elfedi a megosztás gyakorlatainak piaci logikába tagozódását: ott megosztás helyett pontosabb lenne fogyasztásról beszélni (Celata et al. 2017).

Ahogyan azt Juliet Schor (2014) is megállapítja, a gyakorlatban a 'sharing economy' címkévé válik, és a szereplők önmeghatározásának függvénye, hogy a megosztáson alapuló gazdaság résztvevőinek tartják-e magukat. Egyetértünk Dudás és Boros (2019) megállapításával, miszerint a megosztásos gazdasággal foglalkozó diskurzus jelentősége meghaladja a szabályozási szempontokat. Alapvetően befolyásolja társadalmaink működését, hogy milyen tevékenységeket nevezünk megosztásnak és gazdálkodásnak. Dudás és Boros (2019) a „kihasználatlan kapacitások” kiaknázását határozza meg a „valódi” megosztás függvényeként, értelmezésük szerint mindegy, hogy for- vagy nonprofit alapon zajlanak a tranzakciók, azok mindkét esetben lehetnek a közösségi gazdaság részei: ${ }^{1}$ „,amennyiben az egyének alkalmanként adják ki lakásukat olyan esetben, amikor ők nem tartózkodnak benne (pl. nyaralás), úgy ezt a tevékenységet a sharing economy körébe sorolhatjuk. Ezzel szemben, ha az Airbnb-n hirdető háztulajdonos több ingatlannal is rendelkezik és az egyikben életvitelszerüen él, a többi ingatlanját pedig arra használja, hogy hotelként működtesse azokat, úgy ez a fajta tevékenység már a termékszolgáltató gazdaság részét képezi" (Dudás, Boros 2019, 122.).

Érvelésük szerint tehát egyazon szervezeten belül folytatott tevékenységek között megjelenhet a valódi megosztás, amennyiben kihasználatlan kapacitások felajánlásáról, vagy akár azok értékesítéséről van szó. A „kapitalista vállalkozás” által folytatott azon tevékenység azonban, melynek célja valójában „az elnevezés kínálta szimbolikus tőkével járó versenyelőnyök" kihasználása, nem összeegyeztethető a valódi megosztással (Dudás, Boros 2019, 123). Dudáshoz és Boroshoz (2019) hasonlóan Russel Belk (2014) is megkülönbözteti a megosztást a „pszeudómegosztástól”. Belk különböző digitális tereket (platformokat) vizsgál, melyekben a megosztásnak nevezett gyakorlatok különböznek egymástól. Ezek a gyakorlatok eltérhetnek betöltött funkciójuk, valamint szándékuk, motivációjuk alapján. Belk szerint a megosztás gyakorlata önkéntes kölcsönadás, erőforrás-összevonás (pooling) és erőforrás-allokáció, valamint köztulajdon engedélyezett használata lehet, de nem jelent szerződésen alapuló bérbeadást, lízinget vagy engedély nélküli köztulajdon-használatot, esetleg lopást vagy birtokháborítást (Belk 2014). Ezek alapján megkülönbözteti a megosztást a pszeudó-megosztás gyakorlatától: „a pszeudó-megosztás egy üzleti kapcsolat a közösségi megosztás álcájába bújva" (Belk 2014, 10.). A Belk által pszeudó-megosztásnak nevezett (kereskedelmi) folyamatok nem feltétlenül károsak vagy nem kívánatosak a résztvevők, a társadalom vagy a természeti létezők számára: lehetnek normatív értelemben pozitív folyamatok, de - Belk szerint - nem nevezhetők megosztásnak. Belk annak eldöntésére, hogy az adott tevékenység megosztásnak vagy pszeudó-megosztásnak te- 
kinthetö-e, a résztvevők szándékát tekinti meghatározó tényezőnek. A megosztás során az első számú, domináns szándék nem a hozzáférés biztosítása, hanem mások segítése és emberi kapcsolatok kialakítása.

A megosztás társadalmi gyakorlatát vizsgálva Light és Miskelly (2015), illetve John (2016) is a személyes kapcsolódást határozzák meg a valódi és a kereskedelmi célú megosztás közti különbségként: valódi megosztás akkor történik, amikor a tevékenység során létrejönnek személyes kapcsolatok. A megosztási tér résztvevőinek elsődleges célja a kapcsolatteremtés, megjelenik értékként az egymás iránt érzett felelősség és odafigyelés. Benkler (2004) a megosztáson alapuló kezdeményezéseket vizsgálva gyakran a társadalmi megosztás kifejezést (social sharing) használja, utalva ezzel a megosztási rendszerekre jellemző társadalmi normákra és kapcsolatokra. A megosztás e definíciója ellentétben áll azzal a felfogással, mely a megosztást a szabad kapacitások kihasználásának kereskedelmi célú gyakorlatával azonosítja.

A megosztási terek vizsgálatánál - szemben Dudással és Borossal (2019) - Juliet Schor $(2014,5$.$) a for- vagy nonprofit működést határozza meg legfontosabb$ szempontként. A nonprofit megosztási terek (például szerszámmegosztók, magbankok, időbankok, élelmiszerbankok) - a forprofit megosztási terekkel szemben - nem törekednek növekedésük és bevételük maximalizálására, hanem a közösség léptékében szövetkeznek a résztvevők szükségleteinek kielégítésére. Dudás és Boros (2019) fent idézett szemléltető példája, mely szerint az Airbnb (vagy más digitális) platformon egymással párhuzamosan zajlanak megosztáson alapuló gazdasághoz tartozó és gazdasági szolgáltató tevékenységek, ellentétben állnak Benkler (2004), Belk (2014), Schor (2014), Light és Miskelly (2015), illetve John (2016) megosztásfogalmaival. Belk (2014) szerint az Airbnb szabályrendszere nem a megosztásra épül, hanem a szabad kapacitások kihasználására, és a résztvevőket arra ösztönzi, hogy egyrészt növeljék szabad kapacitásaikat, másrészt szálljanak ár- és szolgáltatásminőségi versenybe más vendégéjszakákat biztosító szolgáltatókkal. A felhasználók fó célja nem a személyes kapcsolódás és mások segítése, hanem általában egyéni, gazdasági érdekek miatt kínálják és veszik igénybe ezt a szolgáltatást - szállásadóként a várt bevétel, míg vendégként a hagyományos szálláshelyeknél alacsonyabb ár miatt.

Belk (2014) egy szomszédságot magába foglaló társadalmi tér megosztási szabályait szemlélteti tanulmányában. Példájában a bajba jutott szomszéd autójának akkumulátora lemerül, ezért segítséget kér Tedtől. Ted segít feltölteni az akkumulátort. A folyamat végén a szomszéd 5 dollárt nyújt Ted felé. Ted elutasítja a pénzt, arra hivatkozva, hogy „a szomszédok segítenek egymásnak”. Egyébként is, gondolja Ted, ha már fizetséget fogadna el a szomszédtól, akkor lényegesen többet kérne 5 dollárnál (Belk 2014). Belk példája illusztrálja, hogy különböző megosztási terekben eltérő normák érvényesek. Amennyiben a szomszéd nem Tedet kérte volna meg, hanem egy taxist hívott volna segítségül, úgy abban a társadalmi viszonyrendszerben nem lett volna etikátlan („,szabálytalan”, jószomszédi 
normát áthágó) a pénzforgalom. A pénz tehát nem szorítja ki a megosztást. Vannak olyan személyes kapcsolódást, egymás segítését lehetővé tévő, szükségletkielégítésre irányuló tevékenységek, melyeknek van pénzforgalmi eleme. Azonban a pénzforgalom nem kereskedelmi folyamatban, hanem szükségletkielégítő kapcsolatoknak alárendelve ágyazódik be a megosztási térbe.

A szakirodalmi áttekintésből kitűnik, hogy a megosztásos gazdaság sokfélesége eltérő vizsgálati szempontokat (társadalmi kapcsolódás szándéka vagy kihasználatlan kapacitások biztosítása, forprofit vagy nonprofit jelleg, pénzforgalom jelenléte vagy kizárása) hív életre, és a társadalmi, gazdasági, technológiai változásokkal a megosztás gyakorlata is módosul. A megosztásos gazdaság gyakran ellentmondó jelentéseinek kialakulását a fogalom két elemének paradox viszonya okozza (Belk et al. 2019). A megosztás a „morális gazdaság” területére utal, melynek határait az adott közösség (egymást ismerők) korlátai adják, míg a gazdaság a „piacgazdaságot” írja le, ahol nagyszámú idegen ember cserél árut. A gazdaság eltérő értelmezései egymásnak ellentmondó normákat és jelentéseket eredményezhetnek. Ezt az ellentmondást - véleményünk szerint - a gazdaság szubsztantív értelmezése (Polányi 1976) oldhatja fel, melyet a következő fejezetben mutatunk be.

\section{Eltérő gazdaság-fogalmak a megosztásos gazdaság értelmezésében}

A gazdaságtörténész és -antropológus Polányi Károly (1976) általános gazdasági elméletében elkülöníti egymástól a gazdaság radikálisan eltérő, formális és szubsztantív megközelítését (Zsolnai 2018). A gazdaság formális jelentése szerint „a gazdálkodás a szűkösen rendelkezésre álló eszközök közötti racionális választás valamely cél elérése érdekében" (Zsolnai 1987, 127.). A gazdaság szubsztantív értelmezése alapján a gazdálkodás ,az ember és a környezete közötti kölcsönhatás intézményesített folyamata, amely a szükségletkielégítés anyagi eszközökkel való folyamatos ellátását biztosítja" (Polányi 1976, 236.). A szubsztantív megközelítés szerint tehát a gazdálkodás célja a megélhetés biztosítása a természeti környezettel és a társadalom többi tagjával interakcióban (Zsolnai 2018).

A gazdaság formális és szubsztantív megközelítései alapján radikálisan eltérő módon értelmezhetjük a megosztásos gazdaságot. A gazdálkodás formális jelentése - az akár mesterségesen, tulajdonjogok mentén kialakított - szűkösség által előidézett választási helyzetre utal (Polányi 1976, 236.). Itt a megosztás a kapacitások kihasználásának növelését lehetővé tévő folyamatokat jelenti, melyek (regisztrált) pénzforgalommal járó tevékenységeket takarnak. Ezzel szemben a gazdaság szubsztantív megközelítése a gazdálkodást nem korlátozza a piaci cserére, azt a szükségletkielégítés, ember és környezetének kapcsolata, függőségi viszonya mentén értelmezi. Eszerint a megosztásos gazdaság szereplői eltérő racionalitások alapján, sokféleképpen szerveződhetnek. Míg a formális megközelí- 
tés szürőjén keresztül csupán egyéni gazdasági szereplőket látunk, akik a szükösség mentén szervezik tevékenységeiket, a szubsztantív szemlélet segíthet meghatározni a megosztásos gazdaság helyét a társadalomban, illetve fel- és megismerni az eltérő racionalitásokat a különböző megosztási terekben.

Polányi a gazdaság szubsztantív megközelítése keretében három egymástól eltérő, empirikusan felfedezhető intézményi logikát nevez meg: a kölcsönösségen alapuló reciprocitást, a redisztribúciót és az árucserét. Az előző fejezetben bemutatott, Tedet és szomszédját érintő példa illusztrálja, hogy ugyanazon tevékenység (egy akkumulátor feltöltése) eltérő intézményi logikák mentén valósítható meg. Polányi tipológiájára támaszkodva, a leírt esetben a reciprocitás mintája alapján jártak el a szomszédok. Ugyanakkor, ha a szomszéd taxit hívott volna segítségül, úgy valószínűleg fizetnie kellett volna, és az akkumulátor feltöltése az árucsere logikája mentén valósult volna meg.

A megosztás gyakorlata évezredes múltra tekint vissza. Új jelenség viszont a megosztásos gazdaság tereinek léptéke: soha ennyi idegen embernek - ilyen alacsony belépési küszöb mellett - nem volt lehetősége koordinálni, szervezni tevékenységét (Benkler 2006 munkáját elemzi Arvidsson et al. 2016; Dudás, Boros 2019). Szintén új jelenség a megosztás gyakorlatának „piacosítása” (Belk et al. 2019). Zsolnai László (2018) a piaci intézményi logika túlterjeszkedésének (market overreach) nevezi azt a folyamatot, amely során a piaci intézményi logika dominánssá válik a társadalmi terekben, az emberek tevékenységeiben. A piaci logika dominanciájába ágyazva kerülnek „,megosztásra” ingatlanok az Airbnb és utazások az Uber platformjain, és válik a megosztási gyakorlat piaci cserévé. A CouchSurfing szállásmegosztó platformon - az Airbnb-vel ellentétben - a megosztási tér szabályzata tiltja a felek közötti pénzforgalmat: így törekszik az árucsere logikájának kiszorítására, a reciprocitás fenntartására. Működnek megosztási terek (például az általunk később bemutatott Miutcánk eszközmegosztó platform), melyekben a kapcsolódó felek maguk dönthetik el, hogy mely intézményi logika mentén szervezik együttműködésüket: segíthetnek egymásnak ingyen, pénz ellenében, esetleg megegyeznek egy jelképes árban, ami lehetővé teszi a kapcsolódást az önérzet csorbulása nélkül. A megosztásos gazdaság szubsztantív megközelítésben történő elemzése tehát rávilágít arra, hogy egyazon tevékenység eltérő logikák mentén valósulhat meg - ennek megfelelően az egyes megosztási terekben eltérő racionalitások intézményesülnek (az Airbnb-n a szállások árucseréje, a CouchSurfingen a reciprocitás logikája érvényesül). Megosztásos gazdaságot érintő vizsgálatunkban ezért az intézményi logikákat is elemzési szempontként alkalmazzuk.

Az eltérő intézményi logikák mellett azt is vizsgáljuk, hogy az érintettek hogyan, milyen folyamatok segítségével tartják fenn ezeket az adott megosztási térben. Vallat (2016) szerint a gazdaság szubsztantív értelmezési keretén túl a megosztáson alapuló gazdaság vizsgálatát érdemes kiegészíteni a közösségi javak szakirodalmának analitikus szempontjaival. A közösségi javak kollektív módon 
fenntartott és szabályozott erőforrások: olyan terek, (alulról induló) szerveződések, melyek tudatosan a piaci logikától eltérő módon alakítják működésüket. A közösségi javak szakirodalmának tanulmányozása ezért alkalmas eszköz lehet annak megértésére, hogy a résztvevők hogyan alakítják, hozzák meg és tartják be a fenntartást szolgáló szabályokat. Vizsgálati szempontjai hozzájárulnak megosztásos gazdasági kezdeményezéseket érintő kutatásunk megalapozásához.

\section{A közösségi javak működtetésének elmélete és gyakorlata}

A közösségi javak mögött olyan önszerveződési gyakorlat áll, melynek keretében a résztvevők tudatosan kooperálnak valamely szükségletük kielégítése céljából. Szabályokat alkotnak és egymás között (harmadik fél bevonása nélkül) ellenőrzik a közösségi javak (például halastavak, erdők, legelők, városi közterek, illetve immateriális javak, mint például a tudás, kulturális értékek) fenntartható használatát és az igazságos hozzáférést (Helfrich, Bollier 2014). Elinor Ostrom (1990) részletesen feltárta a feltételeket, amelyek szükségesek ahhoz, hogy egy közösség hosszútávon fenntartható módon képes legyen egy erőforrás kezelésére állami koordináció és piaci mechanizmusok bevonása nélkül. Mivel a megosztás a közösségi javak szakirodalmában is központi helyet foglal el - Parker és Johansson (2012) megosztott erőforrások kollektív és részvételi koordinációjaként definiálja fogalmat - a közösségi javak kezelésére vonatkozó feltételek a megosztásos gazdaság esetében is relevánsak lehetnek vizsgálati szempontként (Vallat 2016; Bradley, Pargman 2017). A közösségi javak olyan megosztási terekként értelmezhetőek, melyeknek résztvevői külső koordináció bevonása nélkül, maguk kontrollálják, hogy milyen intézményi logikák mentén kapcsolódnak egymással.

Ostrom (1990) értelmezési keretét a hazai szakirodalomban Gyuris Ferenc (2014) közjavakként ${ }^{2}$ definiálja, melyeket rivalizáló és kiszorítható tulajdonságaik alapján osztályoznak (Gyuris 2014). Az Ostrom által eredetileg vizsgált természeti erőforrások közös használatán és fenntartásán túl a szakirodalomban az elmúlt évtizedekben megjelentek az új (Hess 2008) vagy ún. társadalmi közösségi javak (Gyuris 2014). Míg a természeti erőforrásokat vizsgáló, a közösségi javakat gazdasági jószágként kezelő szakirodalomban az erőforrás adott és rivalizáló, addig az új közösségi javak esetében az erőforrások léte társadalmi konstrukció függvénye, ,azokat meg kell alkotni” (Helfrich 2012, 61., idézi Euler 2018). Tipikusan ide tartoznak a digitális kulturális vagy tudásalapú közösségi javak (Hess, Ostrom 2007), például a nyílt forráskódú szoftverek vagy a Wikipédia, illetve a városi közösségi javak (Harvey 2006; Parker, Johansson 2012), például a közösségi kertek. A megosztásos gazdaság példáihoz hasonlóan tehát materiális és immateriális javak közös kezelésére és létrehozására is vonatkozhat a fogalom. Fontos továbbá, hogy a javak rivalizáló és kiszorítható tulajdonságai is gyakran társadalmi konstrukció függvényei, és nem belső (megváltozhatatlan) adottságok. 
A (megosztott) erőforráson túl a létrehozó vagy fenntartó közösség, a létrehozáshoz és fenntartáshoz szükséges tevékenységek, illetve a felhasználásra vonatkozó szabályok és normák is a közösségi javak müködtetésének összetevői (Helfrich, Bollier 2014). Az új közösségi javak szakirodalma rávilágít arra, hogy a 'commons' fogalom főnévi alakban nem fejezi ki ezeknek az elemeknek az összességét, ezért érdemesebb volna a fogalmat igeként ('commoning') használni (Linebaugh 2008; Fournier 2013). A commoning tehát az önszerveződés igei alakja, az adott tér, közösség, erőforrások létrehozását, kezelését, használatát és az ezeket lefektető szabályok és normák működtetését foglalja magában (De Angelis, Harvie 2013).

Az új közösségi javak (commons), illetve a közösségi javak müködtetési gyakorlatának (commoning) vizsgálata egy másik fontos szempontra is rávilágít. Ostrom vizsgálataiban - bár mindvégig kritikus maradt az állami és piaci koordinációt minden esetben hatékonyabbnak feltételező szemlélettel szemben - nem jelenik meg a kapitalizmus kritikája explicit politikai célként. A közösségi javak működtetésével foglalkozó szakirodalom ugyanakkor a közösségi javak létrehozására és fenntartására törekvő társadalmi szerveződéseket - változó mértékben tudatos - antikapitalista mozgalmakként azonosítja (De Angelis 2003; Fournier 2013; Helfrich, Bollier 2014; Kostakis, Bauwens 2014; Federici, Caffentiz 2014; Escobar, 2015; Bauwens, Kostakis, Pazaitis 2019). A mozgalmi szemlélet keretében születő társadalmi szerveződések azért irányulnak közösségi javak létrehozására és fenntartására, hogy minél nagyobb mértékben elkülönüljenek, függetlenedjenek az árupiaci logikától, és kapcsolódásaikat, szükségleteik kielégítését a piacitól különböző, például kölcsönösségen vagy redisztribúción ${ }^{3}$ alapuló intézményi logikák mentén szervezzék meg. A fenti szerzők szerint a közösségi javak müködtetése az árucsere intézményi logikája kiszorításának, és más, főleg reciprocitáson alapuló logikák előtérbe helyezésének színterei.

A közösségi javak szakirodalmának egy része azokat a szempontokat térképezi fel, amelyek alapján egy társadalmi szerveződési formát közösséginek tekinthetünk, illetve leírja azok jellemzőit. Euler szerint a közösségi javak használatának megszervezése (commoning) társadalmi konstrukció függvénye, amiről akkor beszélhetünk, ha az előállítás, az újratermelés/fenntartás és a használat is az erőforrást kezelő közösség tagjai által történik. ők egymásra társakként tekintenek, akiknek egyenlő ráhatásuk van a szabályok és normák alakítására (Euler 2018). Az új közösségi javak gyakran nem egy földrajzilag zárt területen belül jönnek létre. Digitális közösség például a Wikipédia, de más szerveződések - például egy közösségi kert - esetében is túlmutathat a résztvevők köre a halastavat vagy legelőt (rivalizáló jószágot) fenntartó közösségen (Bársony 2020). Az új közösségi javak fenntartói elválhatnak a lazábban kapcsolódó felhasználóktól, akik sokkal inkább fogyasztóként vannak jelen. Eulerrel ellentétben Bradley és Pargman nem zárja ki a közösségi javakat müködtető közösségek esetei közül azokat, ahol kiemelke- 
dik egy, az erőforrás megosztásának motorjaként működő szervezői csoport (Bradley, Pargman 2017).

Míg az Euler által meghatározott kritérium alapján a közösségi (commoning) kezdeményezések résztvevői (ún. peerek) közösen hozzák a szabályokat, addig a Bradley és Pargman által vizsgált új közösségi javak működtetői esetében a szabályokért és azok monitorozásáért gyakran a szervezői csoport felelős. Habár Bradley és Pargman is kiemeli, hogy fontos szempont a termelő/elóállító és felhasználó személyének egysége, ám ha ezek a szereplők mégis elválnak, akkor nem hierarchikus utasítási rendszerben, hanem demokratikus módon hozzák meg a döntéseket. A közösségek fenntartásának legalapvetőbb kritériuma De Angelis (2003), Hess és Ostrom (2007), Linebaugh (2008), Federici és Caffentzis (2014), Kostakis és Bauwens (2014) és Akbulut (2017) szerint is az, hogy - igazodva a résztvevők és a helyi kontextus igényeihez - a szabályokat azok hozzák, akikre vonatkoznak.

A közösségi javakat fenntartó közösségek kialakításának lehetőségeit vizsgálva Kostakis és Bauwens (2014) a tulajdonjog és a kezelés demokratikusságának fontosságát is kiemeli. Míg a hagyományos közösségek esetében egyértelműen az erőforrások (erdő, legelő, halastó) közös tulajdonlásáról beszélhetünk, addig az új közösségek kapcsán a tulajdonjog fogalmának radikális újragondolása jelenik meg (Fournier 2013; Bauwens et al. 2019). Nem az a kérdés, hogy kinek a tulajdonában van az adott erőforrás, hanem, hogy a megosztás tárgya közjószágként rendelkezésre álljon a közösség számára. A tulajdon kérdése így inkább a fenntartáson, illetve annak demokratikus módján keresztül értelmezhető (Kostakis, Bauwens 2014). Azt érdemes tehát vizsgálni, hogy a fenntartásban az adott közösség tagjai milyen mértékben vesznek részt: minden résztvevő egyenlően, vagy az kizárólag egy szűkebb csoport feladata.

A közösségi javakat müködtető közösségek a fenti feltételeket bizonyos szabályok és normák lefektetésével érhetik el. A szabályok célja az erőforrás hosszú távú fenntartásának biztosítása, ám ezek azt is korlátozhatják, hogy kik tudnak belépni egy ilyen közösségbe. Bradley és Pargman (2017) szerint a hagyományos közösségekben a belépési korlátok magasabbak, mivel egy zárt commoning közösségbe kerülni nehezebb, annak feltétele többek között rokonsági kapcsolat is lehet. Ezzel szemben az új közösségeknél a belépési korlátok alacsonyabbak, mivel a cél gyakran egy erőforrás elérhetővé tétele széles körben (Bradley, Pargman 2017).

A közösségi javakat fenntartó közösségekben a cél az erőforráshoz történő egyenlő hozzáférés biztosítása a tagok számára (Hess, Ostrom 2007; Federici, Caffentiz 2014; Akbulut 2017). Fournier (2013) szerint azonban a közösségbe való belépéskor a közösség szabályainak és normáinak elfogadása (például az erőforrás működtetésére vonatkozóan) feladatokat és felelősséget is ró a csatlakozó tagokra. Az erőforráshoz akkor juthatnak hozzá, ha annak fenntartásában is részt vesznek. Fournier ezért a kölcsönösség logikáját tartja a közösségi elven szerve- 
ződő kezdeményezések alapvető mechanizmusának. De a Bradley és Pargman (2017) által vizsgált közösségi kezdeményezésekben megjelenik a pénzforgalom is, ami - a reciprocitás mellett - egyéb intézményi logikára utalhat.

A közösségi javak szakirodalma azért kínál releváns szempontokat tanulmányunkhoz, mert középpontjában jellemzően a reciprocitáson alapuló vagy egyéb (de az árucserét mindenképp más racionalitásoknak alárendelő) intézményi logikák mentén működő megosztási terek állnak. A megosztással foglalkozó szakirodalom főbb gondolatait szintetizálva, a javak közösségi használatára irányuló gyakorlatok főbb vizsgálati szempontjait az 1. táblázat foglalja össze. A táblázat azt is szemlélteti, hogy a megosztásos gazdaság kezdeményezéseit a formális megközelítésen túl saját szempontjaik, saját racionalitásuk mentén is érdemes vizsgálni.

\section{Módszertan}

Tanulmányunk célja, hogy eszközt találjunk a megosztásos gazdaság önellentmondásának, belső feszültségének kezelésére. A megosztással és közösségi javakkal foglalkozó szakirodalom elméleti megfontolásait ezért empirikus eseteken alkalmazzuk. Olyan budapesti kezdeményezéseket választottunk, amelyek azt vallják magukról, hogy a megosztás tevékenységük lényegi eleme. Nem célunk ugyanakkor, hogy a fővárosban vagy Magyarországon működö, megosztáson alapuló kezdeményezésekről átfogó képet nyújtsunk.

A kezdeményezések azonosítását online dokumentumok elemzésével végeztük 2018 szeptembere és októbere között, majd úgy választottuk ki a vizsgált szerveződéseket, hogy azok a megosztás különböző formáit reprezentálják. A szerveződéseket online elérhető adatok alapján, valamint egy, a szerzők által szervezett, a szakirodalom alapján összeállított kérdések mentén vezetett kerekasztal-beszélgetésen nyert empirikus tapasztalatok alapján vizsgáltuk meg. A Budapesti Corvinus Egyetemen, 2018. november 20-án megrendezett, másfél órás kerekasztal-beszélgetés résztvevői a megosztással foglalkozó szerveződések alapítói, kezdeményezői voltak. A hat meghívott kezdeményezés közül az a három került a tanulmány elemzésébe, amelyek lényegi különbségeket mutatnak a megosztás tárgyát és mikéntjét, valamint a szerveződés motivációit illetően, azaz jól szolgálják javasolt elemzési keretünk alátámasztását. A beszélgetésen feltett kérdések azt járták körül, hogy mi motiválta a szervezőket, a kezdeményezések milyen tárgy vagy szolgáltatás megosztását és a megosztás milyen formáit teszik lehetővé, kik a résztvevők, illetve kik és hogyan hozzák a szabályokat. A beszélgetés résztvevőin és a szerzőkön kívül körülbelül 25 fős hallgatóság vett részt az eseményen. 


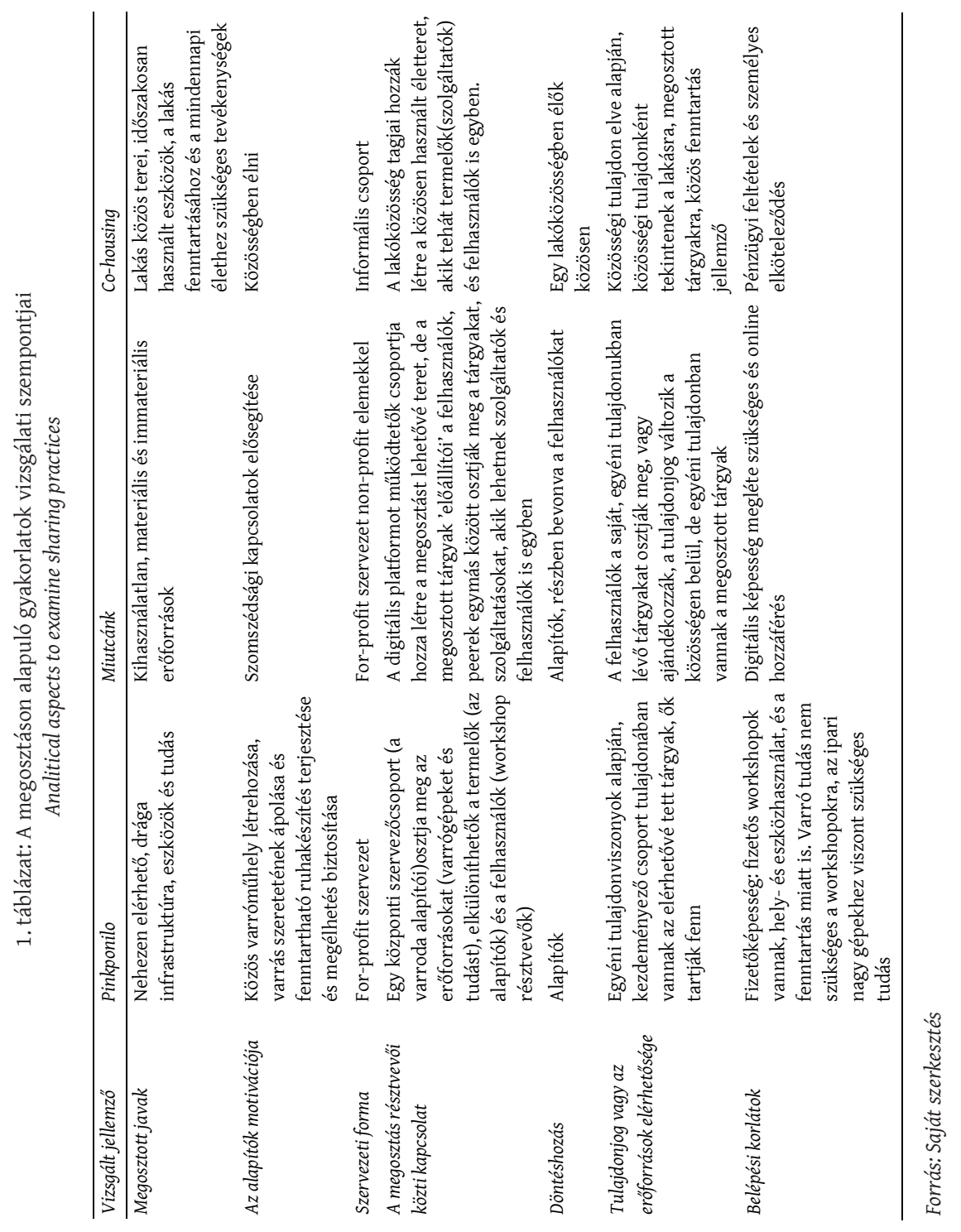




\section{A megosztás gyakorlata három eltérő közösségben}

A vizsgált kezdeményezések a ruházkodás, a mindennapi élethez szükséges használati eszközök és a lakhatással kapcsolatos szükségletek kielégítését célozzák materiális és/vagy immateriális javak megosztásával. A Pinkponilo egy olyan közösségi varroda és ruhajavító műhely, ahol az alapítók saját termékek eloállítása és értékesítése mellett workshopok keretében tanítják meg az érdeklődőknek a varrógépek használatát, különféle ruhadarabok elkészítését. A varroda létrehozását az alapítók varrás iránti szenvedélye motiválta. Olyan helyet álmodtak meg, ahol kiélhetik varrás iránti szeretetüket, népszerüsíthetik a fenntartható ruhakészítést, és ez egyben anyagi megélhetést is biztosít számukra. A műhely, a géppark és a szükséges eszközök pénzügyi fenntartása céljából, a saját termékek eloállításán túl oktatási tevékenységet is végeznek, melynek keretében másokat tanítanak varrni. Ezek olyan, általában az alapítók által szervezett csoportos ruhakészítő és -javító, táska- vagy akár fehérnemű-készítő foglalkozásokat takarnak, melyek előre meghatározott részvételi díj ellenében vehetők igénybe. Noha ezek a foglalkozások piaci szolgáltatásokként jelennek meg a varróműhely működésében, az egyik alapító kifejtette, hogy „nagyon jó élmény, amikor vadidegen emberek segítenek egymásnak, együtt dolgoznak" (alapító, Pinkponilo). A kezdeményezésben tehát a résztvevők közötti tudásmegosztás is megjelenik. E foglalkozásokon túl egyéni érdeklődőket is szívesen látnak mühelyükben, akik saját ötleteiket, ruhadarabjaikat szeretnék életre kelteni. Ez utóbbi esetben az eszközhasználatért cserébe a fix áron alapuló piaci tranzakción (eszközök bérlésén) kívül különböző együttmüködési konstrukciók is megfigyelhetőek. Barter megállapodások is létrejöttek, például egyes felhasználók az eszközhasználatot workshopok szervezésével és az oktatásban részvétellel „fizették meg”. Ebben az esetben azonban már sokkal inkább együttműködő partnerekről beszéltek az alapítók, mintsem felhasználókról.

A második eset a Miutcánk nevű online platform, ahol a szomszédok szívességeket és eszközöket kérhetnek és oszthatnak meg másokkal. Az alapítók lokális közösségépítő platformként utalnak a kezdeményezésre, mert kifejezett céljuk, hogy a megosztáson keresztül szomszédsági kapcsolatok jöjjenek létre: ,ismerjük meg az egy környéken élóket, olyanokkal tudjunk kommunikálni, akikhez papucsban át lehet sétálni" (alapító, Miutcánk). Az online platformot létrehozó csoport egy baráti társaságból nőtt ki, akik eleinte szabadidejükben foglalkoztak az online felület

fejlesztésével és marketingjével. A kezdeményezés nonprofit formában működik, azonban az alapító csoport célja a jövedelemszerzés, melynek módját jelenleg is keresik. A ma körülbelül 43700 regisztrált főt számláló felületen eszközök (például létra, kalapács, fúró, kerékpárpumpa), szolgáltatások (például fordítás, kutyasétáltatás), illetve információ megosztásával segítik egymást a felhasználók. A résztvevők általában ingyen osztják meg elérhető eszközeiket vagy tudásukat a szomszédokkal. Noha az ingyenes felajánlásokon túl előfordul használt eszközök 
vagy szolgáltatások fizetség ellenében való átadása is, a megosztási tevékenység során általában nem jelenik meg pénzforgalom. A platform müködését az alapítószervező csapat szabályozza, de arról a felhasználók maguk döntenek, hogy a platformon milyen tárgyakat és szolgáltatásokat osztanak meg. Törekednek arra, hogy a legaktívabb felhasználókat bevonják a szervezési folyamatba is: például események szervezésekor önkéntes csapatot próbálnak kialakítani belőlük, s ők így egy „,nem létező szavazórendszerben szavazati jogot kapnak” (alapító, Miutcánk), vagyis alakíthatják a megosztás, a kapcsolódás terét. Emellett kérdőívek, interjúk segítségével próbálja a szervezői gárda a felhasználók visszajelzéseit beépíteni a működésbe.

Harmadik esettanulmányunk a co-housing - közös lakhatás - életformáját vizsgálja, főként a „Közösségben Élni” ${ }^{4}$ nevű kezdeményezés alapítóinak tapasztalatai alapján. A co-housing vagy „közösségben élés” olyan lakhatási forma, melynek keretében egy, általában kisebb csoport tudatosan, aktív közösségi részvétel köré szervezi a lakhatását. Az emberek, akik ezt az életformát választják, általában egy nagyobb lakásban vagy házban élnek együtt. Minden lakó rendelkezik saját privát térrel (például hálószobával), míg az időszakosan használt tereket (mint a konyhát, nappalit, fürdőszobát és kertet/teraszt) közösen használják, és osztoznak a fenntartási költségeken. Az együttlakás célja elsősorban nem a költségek csökkentése, hanem maga a közösségben élés, az egymáshoz kapcsolódás. A közösségben élés túlmutat a fizikai terek megosztásán. A nem állandóan használt tárgyak (mosógép, edények stb.), egymásnak és a közösségnek tett szívességek (például közösségi vásárlás, vacsorakészítés) és más szervezett programok, hobbitevékenységek (mint kertészkedés, torna) megosztását is lehetővé teszi ez a lakhatási forma. Az egymástól elvárt tevékenységeket, például a közös terek kialakítását és fenntartását (takarításokat, javításokat), a lakók a közösen hozott szabályok alapján határozzák meg.

A vizsgált kezdeményezések a létfenntartáshoz szükséges különböző igények megosztáson keresztüli kielégítéseként is értelmezhetőek. A szakirodalom alapján felállított elemzési keret (1. táblázat) segítségével célunk, hogy a megosztásos gazdaság sokszínűségét illusztráljuk, és közben fejlesszük magát az elemzési keretet is, mely révén e kezdeményezések vizsgálhatóak. A kezdeményezések jellemzőinek összefoglalása a 2. táblázatban látható.

A megosztott erőforrások mindegyik esetben materiális (varrógépek, tárgyak, lakás) és immateriális (varrni tudás, szívességek, közös programok) javakat is takarnak. A résztvevők kapcsolatát tekintve, a közösségi javak szakirodalmában megjelenő egyenlő társak jelensége (akik az adott erőforrás előállítói és használói is egyben) a közösségben élőkre jellemző leginkább. A Miutcánk esetében elkülönül egy szervezői csoport, akik létrehozzák és működtetik a megosztást lehetővé tévő platformot. Ugyanakkor a platform felhasználói egyaránt lehetnek a tárgyak és szolgáltatások megosztói (eloaállítói) és fogyasztói. A varrodában az alapítók osztják meg a tárgyaikat (varrógépeiket) és tudásukat másokkal, de egyes esetek- 


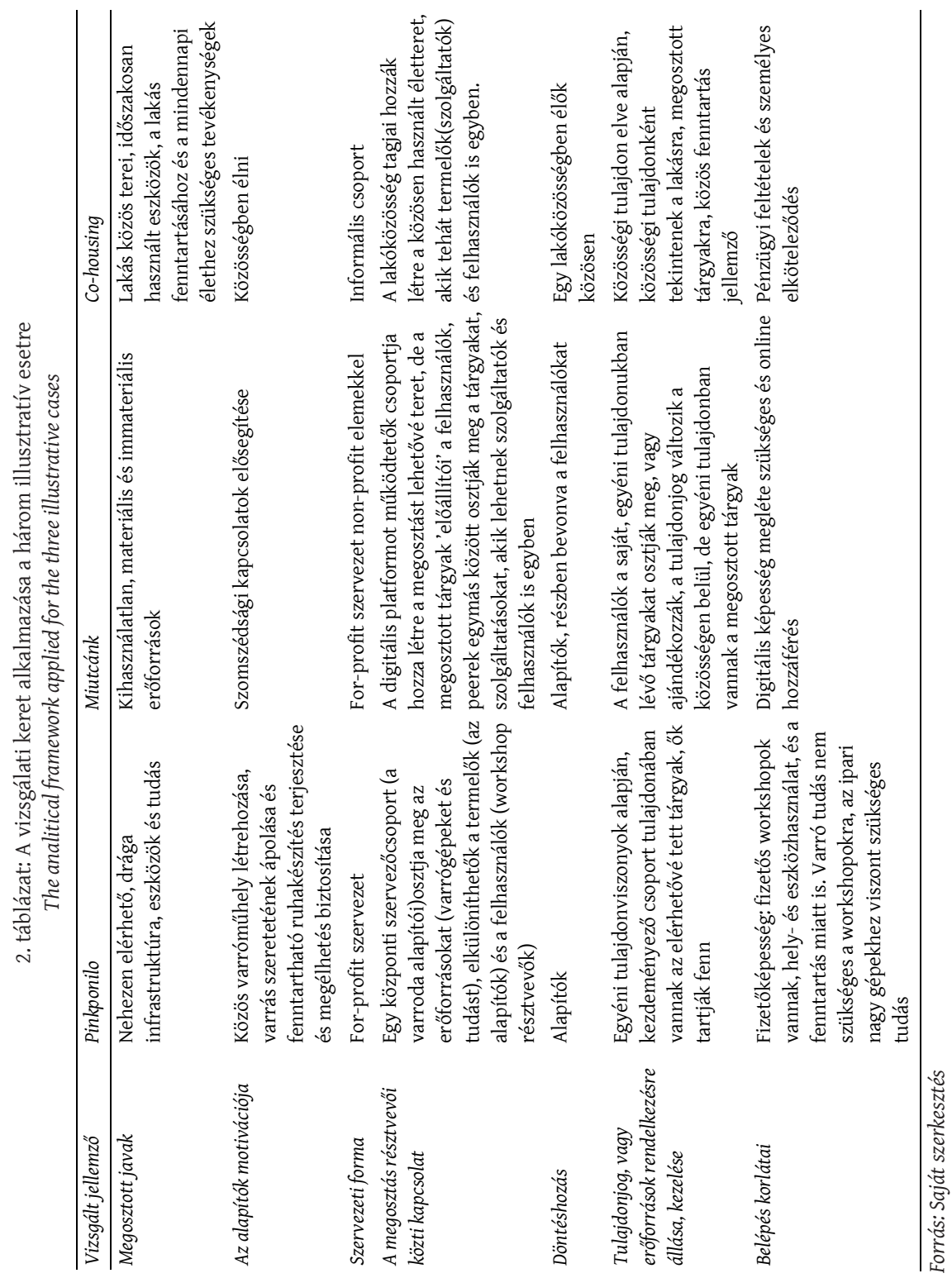


ben - amikor például barter megállapodásokat kötnek - a felhasználók is előállítókká, társakká válhatnak. Ugyanakkor ez utóbbi eset nem meghatározó.

A döntéshozatalra olyan kulcsfolyamatként tekintünk, melynek keretében alakítható, hogy milyen normák érvényesülhetnek, és milyen logikák intézményesülhetnek (mi a racionális viselkedés) az adott megosztási térben. A varrodában a döntéseket általában a két alapító hozza. A Miutcánk esetében is jellemzően a szervezői csapat dönt, de a legaktívabb felhasználókat próbálják az alkotásba is bekapcsolni, akiknek így több beleszólásuk lehet a folyamatba. A három eset közül a leginkább demokratikus döntéshozási formát a közösségben élők gyakorolják, hiszen itt például a megosztott terek használatáról vagy a házimunka felosztásáról szóló szabályok közös kialakítása alapelv. A döntéshozás módja közösségenként változó lehet, ezt az adott lakóközösség határozza meg.

A döntéshozatalhoz szorosan kapcsolódik a tulajdon kérdése. A közösségek működésének meghatározó tényezője az erőforrások közös tulajdonlása. A közös tulajdon biztosítja, hogy ne egy szűk csoport rendelkezzen az erőforrásokról és azok megosztásának, felhasználásának szabályairól, hanem azokra a tagok széles köre gyakorolhasson befolyást. Ezért valósul meg leginkább a közösségben élők esetében a kollektív döntéshozatal, hiszen a megosztott közös terek és a tárgyak egy része (bútorok, konyhai felszerelés, mosógép stb.) közös tulajdont képvisel. Gyakran a megosztott lakás is közös tulajdonban van, vagy közösen bérlik. A megosztott eszközök is inkább a közösség, mintsem az egyes lakók tulajdonát képzik, függetlenül attól, hogy azokat közösen vásárolták vagy egyéni tulajdonban lévő tárgyaikat ajánlották fel a lakóközösség számára. Vannak természetesen egyéni felhasználású (és egyéni tulajdonban lévő) személyes tárgyak, illetve a tereknek és tárgyaknak is csak egy része megosztott. Nincs például vagyonközösség, a lakók önálló jövedelemmel és saját lakrésszel (általában hálószobával is) rendelkeznek. A közösségben élőkkel ellentétben, a Pinkponilo esetében az alapítók, a Miutcánkéban a felhasználók teszik elérhetővé saját tulajdonukat mások számára. A megosztásos gazdaság szakirodalmában ugyanakkor Belk (2014) utal rá, hogy a Miutcánkhoz hasonló megosztó platformokon - ahol a felhasználók feleslegessé vált vagy ki nem használt eszközeiket osztják meg, és azok a közösségen belül cserélnek gazdát - a megosztott tárgyak tekinthetőek a közösség tulajdonának.

A tulajdonosi szerkezet nemcsak a szabályok kialakításába való beleszólás lehetősége miatt fontos szempont. Annak kapcsán is érdekes, hogy ösztönzi-e a tagok részvételét az erőforrások fenntartásában és újratermelésében. Azt tehát, hogy létrejön-e a tulajdonosi szerkezet közösséggel szembeni felelős formája, a megosztott erőforrások előállításának és működtetésének demokratikusságán keresztül vizsgáljuk: azt kutatjuk, hogy a tagok mennyire vehetnek részt egyenlő mértékben a közösségi döntéshozatalban. A demokratikusság leginkább a közösségben élőkre jellemző, mivel itt a működés alapja a közös terek, tárgyak fenntartásában való, mindenkire vonatkozó részvétel (a konyha takarítása, közös helyiségek kifestése például minden lakó felelőssége). A Miutcánk és a Pinkponilo 
sokkal inkább egyéni tulajdonban lévő eszközök köré szerveződő megosztási terek. Ezekben a közösségekben a kezdeményező csoport és a felhasználók egyéni felelőssége, hogy a tulajdonukban lévő tárgyakat müködtessék, és a platformon megosztott tárgyak vagy a workshopokon használt varrógépek fenntartására, kezelésére a felhasználók nem feltétlenül tekintenek közös feladatként.

A belépés e kezdeményezésekbe különböző feltételekhez kötött, melyek között találunk anyagi természetűeket és személyes képességekhez kapcsolódókat is. A Miutcánk platformjához csatlakozás feltétele minimális digitális képességek és internet-hozzáférés megléte. A Pinkponilo workshopjainak látogatása és a varrógépek használata fizetőképességhez kötött (de varrni tudás például nem szükséges). A közösségben élők esetében a belépési korlát magasabb: a szükséges anyagi feltételek (lakhatás finanszírozásának képessége) mellett az előző két kezdeményezéshez képest hosszabb távú elköteleződés szükséges az együttélés elve mellett. Ebből adódóan a közösségben élők zártabb csoportot alkotnak a másik két platformhoz képest: utóbbiak esetében a be- és kilépés is rugalmasabb.

A javak megosztásának, a szükségletek kielégítésének többféle logikája intézményesül a vizsgált kezdeményezésekben. A Pinkponilo esetében piaci csere keretében, vagyis fizetség ellenében veszik igénybe a szolgáltatást a felhasználók. Ez Belk (2014) definíciója alapján a rövidtávú bérlés kategóriájába esik. Emellett azonban megjelenik a barter néhány együttműködő partner esetében, ami sokkal inkább a reciprocitás logikájával írható le, a ruhakészítő workshopokon résztvevők pedig az önellátás egy formáját sajátítják el. A Miutcánk platformján keresztül a felhasználók jellemzően a reciprocitás logikájával leírható formában teszik elérhetővé tárgyaikat. Ingyen adják kölcsön azokat vagy tesznek szívességet másoknak, illetve ajándékozással és barter megállapodásokkal is találkozhatunk. Alkalmanként megjelennek a fizetség ellenében nyújtott, tehát a piaci csere logikáján alapuló szolgáltatások is. A közösségben élés során a megosztás intézményesült logikája a reciprocitás és az önellátás. A lakóközösség tagjai egymásnak és a közösségnek ingyen tesznek szívességeket (intézik el például a bevásárlást), ajánlják fel a közösség számára időszakosan használt eszközeiket (mondjuk az edényeket), és maguk tartják fenn közös tereiket (például takarítanak). A bemutatott kezdeményezések esetében tehát különböző - a Polányi (1976) által meghatározottaktól akár eltérő - intézményi logikák figyelhetőek meg, amelyek egymással párhuzamosan is jelen lehetnek.

\section{Összefoglalás}

Írásunkban a megosztásos gazdaság „önellentmondására”, belső feszültségére hívtuk fel a figyelmet. Polányi (1976) és Belk et al. (2019) gondolataira építve amellett érveltünk, hogy a belső feszültséget a társadalom és a gazdaság (hamis) dichotómiája okozza, melyben a megosztás a társadalom, az árucsere logikája pe- 
dig a gazdaság terébe tartozik. Ugyanakkor a társadalom és a gazdaság elkülönítése a gazdaság formális megközelítésének sajátja. A formális megközelítés elméleti (nem empirikus) eredetű, szűken értelmezi a gazdaság fogalmát, a gazdálkodás racionalitása a szűkösség által teremtett választási helyzetre korlátozódik. Ezzel ellentétben a szubsztantív megközelítés a gazdaságot a társadalom részének tekinti. A szubsztantív megközelítés eltérő (nem kizárólag árucsere alapú) interakciókat enged meg, többféle racionalitás és intézményi logika mentén. A kérdés a megosztásos gazdaság esetében is az, hogy milyen szabályok, intézményi logikák mentén kapcsolódhatnak össze egymással és környezettükkel az érintettek, és kik alakíthatják e szabályokat. Tanulmányunkban ezért támaszkodtunk a közösségi javak szakirodalmára (is): itt a vizsgálat egyik fókusza, hogy az adott közösség, megosztási tér résztvevői miként intézményesítik az általuk preferált intézményi logikákat, hogyan képesek azok egymáshoz mért viszonyát (például az árucsere alárendelt szerepét) befolyásolni, szabályozni.

Három, egymástól jelentősen eltérő megosztási teret mutattunk be illusztratív céllal, melyekben a megosztás és gazdálkodás különböző gyakorlatai jelennek meg. Ugyanaz a tevékenység (például egy ruha megvarrása) megvalósulhat a Pinkponilo varrodájában varrógép bérlésével, a Miutcánk platformja által összekötve szívességi alapon, illetve a Közösségben Élni tagjai között egymás felé vállalt kötelezettség keretében. De egy kezdeményezésen belül is megfigyelhetünk különféle, akár egymással keveredő intézményi logikákat.

Szemben a formális megközelítés szúkösség-választás sémájával, az intézményi logikák és a fenntartásukat meghatározó szempontok vizsgálata segíthet a megosztási terek, kezdeményezések saját belső feltételeinek, racionalitásának a megismerésében. Polányi (1976) általános gazdaságelmélete és a közösségi javak szakirodalma lehetővé teszi egy eltérő intézményi logikák mentén gazdálkodó, együttműködő (megosztó) társadalom elképzelését, melyben a gazdaság a társadalom része és a gazdálkodás sokféleképpen racionális.

Tanulmányunkban különféle megosztási terek belső tulajdonságait vizsgáltuk. A piaci logika által dominált társadalomban azonban bármilyen szerveződés - hacsak nem egy teljes mértékben izolált kommunáról van szó - elkerülhetetlenül piaci műveleteket/kereskedelmi tevékenységet is végez. Érdemes lenne ezért megvizsgálni, hogy a tanulmányban szereplő szervezetekhez hasonló kezdeményezések milyen kapcsolatban állnak a domináns piaci logikával, és hogyan lépnek interakcióba a piac más szereplőivel.

\section{Jegyzetek}

1 Tipológiájukban a „sharing economy, a közösségi gazdaság és a megosztáson alapuló gazdaság fogalmakat egymás szinonimáiként használ[ják]" (Dudás, Boros 2019, 125).

2 A közjavak kifejezés a neoklasszikus közgazdasági iskola koncepciója, mely a javakat két szempont alapján osztályozza: az adott jószág fogyasztása korlátozza-e mások fogyasztását 
(rivalizáló tulajdonság), illetve hogy a fogyasztók kizárhatók-e a jószág fogyasztásából. Ebben a felosztásban az osztályozás merev, az adott jószág besorolása „veleszületett” tulajdonságnak minősül (Gyuris 2014, 17-18.). A „mozgalmi” szakirodalom egyik sarokpontja, hogy sok esetben társadalmi konstrukció függvénye az adott jószág hozzáférhetősége és rivalizáló tulajdonsága - az osztálytípus nem feltétlenül a jószág „veleszületett” tulajdonsága. Immateriális javak esetében például a hozzáférhetőség lehet fizikai (internet-hozzáférés) vagy nem fizikai (tulajdonjog) feltételek függvénye, mely feltételek valamilyen mértékben alakíthatóak (tehát nem veleszületett tulajdonságai az adott jószágnak). A szövegben mi következetesen a közösségi javak kifejezést használjuk, amely hordozza jelentésében az alakíthatóságot, a változtathatóságot. A kapcsolódások sokszínűségére lásd például Gibson-Graham és Dombroski (2020) felsorolását. A következetesség és koherencia érdekében írásunkban mi maradunk Polányi tipológiájának alkalmazásánál.

4 A „Közösségben Élni” nevű kezdeményezés alapítói azokat a személyeket támogatják, akik a cohousing életformát kívánják követni, az érdeklődők összekötésével, tanácsadás és szakpolitikai ajánlások révén.

\section{Köszönetnyilvánítás}

Ezúton köszönjük a cikk megírását inspiráló kezdeményezések alapítóinak, képviselőinek részvételét a „Kaláka a 21. században, avagy napjaink közösségi kezdeményezései” kerekasztal-beszélgetésen, és hogy tudásukat, tapasztalatukat megosztották velünk. Köszönettel tartozunk Pataki Györgynek, aki javaslataival, megjegyzéseivel és tanácsaival támogatta és inspirálta a tanulmány megírását. Köszönettel tartozunk továbbá Zsolnai Lászlónak, aki az egyik szerző doktori témavezetőjeként írásaival és gondolataival segítségünkre van. Köszönjük a bírálóknak és az olvasószerkesztőnek a hozzájárulásukat.

A kutatást az EFOP-3.6.2-16-2017-00007 azonosító számú, „Az intelligens, fenntartható és inkluzív társadalom fejlesztésének aspektusai: társadalmi, technológiai, innovációs hálózatok a foglalkoztatásban és a digitális gazdaságban" címü projekt támogatta. A projekt az Európai Unió támogatásával, az Európai Szociális Alap és Magyarország költségvetése társfinanszírozásában valósul meg.

\section{Irodalom}

Akbulut, B. (2017): Commons. In: Spash, C.L. (ed.): Handbook of Ecological Economics. Routledge, London and New York, 395-403.

Arvidsson, A., Caliandro, A., Cossu, A., Deka, M., Gandini, A., Luise, V., Orria, B., Anselmi, G. (2016):: Commons based peer production in the information economy. https://www.academia.edu/ 29210209/Commons_Based_Peer_Production_in_the_Information_Economy (Letöltés: 2019.03.10.)

Bársony, F. (2017): The age of sharing by Nicholas A. John. Corvinus Journal of Sociology and Social Policy, 1., 146-152. https://doi.org/10.14267/CJSSP.2017.01.11

Bársony, F. (2020): Városi közösségi kertek Magyarországon. Tér és Társadalom, 1., 140-159. https:// doi.org/10.17649/TET.34.1.3071

Bauwens, M., Kostakis, V., Pazaitis, A. (eds.) (2019): Peer to Peer: The Commons Manifesto. University of Westminster Press, London

Belk, R., Eckhardt, G., Bardhi, F. (2019): Introduction to the Handbook of the Sharing Economy: the paradox of the sharing economy. In: Belk, R., Eckhardt, G., Bardhi, F. (eds.): Handbook of the Sharing Economy. Edward Elgar Publishing, Cheltenham, UK, 1-8.

Belk, R. (2014): Sharing Versus Pseudo-Sharing in Web 2.0. Anthropologist, 1., 7-23. https://doi.org/ 10.1080/09720073.2014.11891518 
Benkler, Y. (2004): Sharing nicely: on shareable goods and the emergence of sharing as a modality of economic production. The Yale Law Journal, 2., 273-358. https://doi.org/10.2307/4135731

Benkler, Y. (2006): The Wealth of Networks: How Social Production Transforms Markets and Freedom. Yale University Press, New Haven and London

Bradley, K., Pargman, D. (2017): The sharing economy as the commons of the 21st century. Cambridge Journal of Regions, Economy and Society, 2., 231-247. https://doi.org/10.1093/cjres/rsx001

Celata, F., Hendrickson, C.Y., Sanna, V.S. (2017): The sharing economy as community marketplace? Trust, reciprocity and belonging in peer-to-peer accommodation platforms. Cambridge Journal of Regions, Economy and Society, 2., 349-363. https://doi.org/10.1093/cjres/rsw044

De Angelis, M. (2003): Reflections on alternatives, commons and communities. The Commoner, 6., 1-14. http://www.thecommoner.org (Letöltés: 2019. március 10.)

De Angelis, M., Harvie, D. (2013): The Commons. In: Parker, M., Cheney, G., Fournier, V., Land, C. (eds.): The Routledge Companion to Alternative Organisation. Routledge, London, 280-294.

Dudás, G., Boros, L. (2019): A közösségi gazdaság (sharing economy) definiálásának dilemmái. Tér és Társadalom, 1., 107-130. https://doi.org/10.17649/TET.33.1.3058

Euler, J. (2018): Conceptualizing the Commons: Moving Beyond the Goods-based Definition by Introducing the Social Practices of Commoning as Vital Determinant. Ecological Economics, 143., 10-16. https://doi.org/10.1016/j.ecolecon.2017.06.020

Escobar, A. (2015): Degrowth, postdevelopment, and transitions: a preliminary conversation. Special Feature: Review Article Socially Sustainable Degrowth as a Social-Ecological Transformation. Sustainability Science, 3., 451-462. https://doi.org/10.1007/s11625-015-0297-5

Federici, S., Caffentiz, G. (2014): Commons against and beyond capitalism. Community Development Journal, 1., 92-105. https://doi.org/10.1093/cdj/bsu006

Fournier, V. (2013): Commoning: on the social organisation of the commons. M@n@gement, 4., 433-453. https://doi.org/10.3917/mana.164.0433

Gibson-Graham, J.K., Dombroski, K. (2020): Introduction to The Handbook of Diverse Economies: inventory as ethical intervention. In: Gibson-Graham, J.K., Dombroski, K. (eds.): Handbook of Diverse Economies. Edward Elgar Publishing, Cheltenham, UK, 1-24.

Gyuris, F. (2014): A közjavak térbelisége. Tér és Társadalom, 4., 15-39. https://doi.org/10.17649/TET. 28. 4.2650

Harvey, D. (2006): Space of Global Capitalism: Towards a Theory of Uneven Geographical Development. Verso, New York

Helfrich, S. (2012): Common goods don't simply exist - they are created. In: Bollier, D., Helfrich, S. (eds.): The Wealth of the Commons: A World Beyond Market and State. Levellers Press, Amherst, MA, USA, 61-67.

Helfrich, S., Bollier, D. (2014): Commons. In: D’Alisa, G., Demaria, F., Kallis, G. (eds.): Degrowth: a vocabulary for a new era. Routledge, New York and London, 75-78.

Hess, C. (2008): Mapping the new commons. Az IASC „Governing Shared Resources: Connecting Local Experience to Global Challenges” c. 12. konferenciáján (University of Gloucestershire, Cheltenham) elhangzott előadás anyaga. http://surface.syr.edu/cgi/viewcontent.cgi?article=1023\&context=sul (Letöltés: 2019. március 16.)

Hess, C., Ostrom E. (eds.) (2007): Understanding Knowledge as a Commons: from Theory to Practice. The MIT Press, Cambridge, MA, London, England

John, N.A. (2013): The Social Logics of Sharing. The Communication Review, 3., 113-131. https:// doi.org/10.1080/10714421.2013.807119

John, N.A. (2016): The age of sharing. Polity, Cambridge

Kostakis, V., Bauwens, M. (2014): Network Society and Future Scenarios for a Collaborative Economy. Palgrave Macmillan, Basingstoke https://doi.org/10.1057/9781137406897

Light, A., Miskelly, C. (2015): Sharing Economy vs Sharing Cultures? Designing for social, economic and environmental good. Interaction Design and Architecture(s) Journal, 24., 49-62.

Linebaugh, P. (2008): Magna Carta Manifesto: Liberties and Commons for All. University of California Press, Berkeley, CA 
Ostrom, E. (1990): Governing the Commons. The Evolution of Institutions for Collective Action. Cambridge University Press

Parker, P., Johansson, M. (2012): Challenges and Potentials in Collaborative Management of Urban Commons. In: Besednjak Valic, T., Modic, D., Lamut, U. (eds.): Multi-faceted nature of collaboration in the contemporary world. Vega Press, Melbourne, 92-113.

Polányi K. (1976): Az archaikus társadalom és a gazdasági szemlélet. Gondolat Kiadó, Budapest

Price, J.A. (1975): Sharing: The Integration of Intimate Economics. Anthropologica, 1., 3-27. https:// doi.org/10.2307/25604933

Schor, J. (2014): Debating the Sharing Economy. Great Transition Initiative. http://www.greattransition.org/publication/debating-the-sharing-economy (Letöltés: 2019. február 20.)

Szabó, K. (2017): Intézményi vállalkozások: Intézményi újítások - létező intézmények kombinációjával. Vezetéstudomány, 3., 2-14. https://doi.org/10.14267/VEZTUD.2017.03.01

Vallat, D. (2016): An Alternative to State-Market Dualism: The Sharing Economy. Practical and Epistemological Questions. SASE 28th Annual Conference, June 24-26, 2016, University of California, Berkeley

Wittel, A. (2011): Qualities of Sharing and their Transformations in the Digital Age. International Review of Information Ethics, 9., 3-8.

Zilahy, Gy. (2016): Sustainable business models - What do management theories say? Vezetéstudomány, 10., 62-72.

Zsolnai L. (1987): Mit ér az ökonómia, ha magyar? Ökológiai és humán kérdések. Közgazdasági és Jogi Könyvkiadó, Budapest

Zsolnai L. (2018): Ethics, Meaning, and Market Society. Routledge, New York 